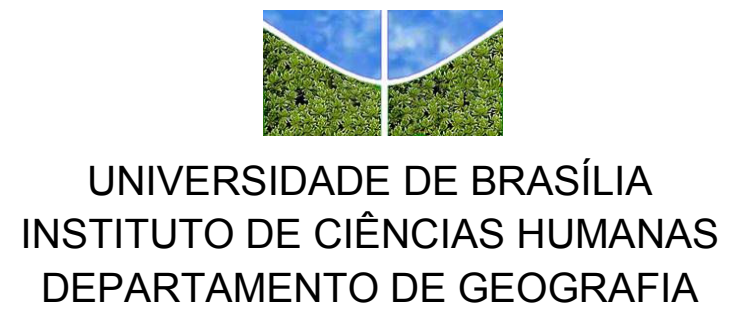

O IMAGINÁRIO AMBIENTAL, PRÁTICAS ESPACIAIS E EXPANSÃO URBANA: ÁREAS LIMÍTROFES DA ARIE JK - DF

DIEGO LOPES BERGAMASCHI

ORIENTADORA: PROF. DRA. MARÍLIA LUÍZA PELUSO

BRASÍLIA

JULHO/2009 
DIEGO LOPES BERGAMASCHI

O IMAGINÁRIO AMBIENTAL, PRÁTICAS ESPACIAIS E EXPANSÃO URBANA: ÁREAS LIMÍTROFES DA ARIE JK - DF

Monografia de Graduação submetida ao Departamento de Geografia da Universidade de Brasília, como parte dos requisitos necessários à obtenção do Grau de Bacharel em Geografia.

ORIENTADORA: PROF. DRA. MARÍLIA LUÍZA PELUSO

BRASÍLIA

JULHO/2009 
UNIVERSIDADE DE BRASÍLIA

INSTITUTO DE CIÊNCIAS HUMANAS

DEPARTAMENTO DE GEOGRAFIA

\title{
O IMAGINÁRIO AMBIENTAL, PRÁTICAS ESPACIAIS E EXPANSÃO URBANA: ÁREAS LIMÍTROFES DA ARIE JK - DF
}

\author{
DIEGO LOPES BERGAMASCHI
}

MONOGRAFIA DE GRADUAÇÃO APROVADA PELA BANCA EXAMINADORA, CONSTITUÍDA POR:

PROFESSORA DRA. MARÍLIA LUÍZA PELUSO - UNIVERSIDADE DE BRASÍLIA (ORIENTADORA)

PROFESSORA MESTRE MARIANA ZERBONE ALVES DE ALBUQUERQUE FACULDADE PROJEÇÃO

(EXAMINADORA EXTERNA)

PROFESSOR MESTRE GILBERTO ALVES DE OLIVEIRA - UNIVERSIDADE DE BRASÍLIA

(EXAMINADOR INTERNO)

BRASÍLIA, 03 DE JULHO DE 2009 
FICHA CATALOGRÁFICA

\section{BERGAMASCHI, DIEGO LOPES}

O Imaginário Ambiental, Práticas Espaciais e Expansão Urbana: Áreas limítrofes da ARIE JK - DF, 47 p., 297 mm, (UnB-IH-GEA, Graduação, 2009).

Monografia de Graduação - Universidade de Brasília. Departamento de Geografia.

1 Práticas espaciais

2. Espaço Urbano

3. Imaginário Ambiental

4. Discurso

I. UnB-IH-GEA

II. Título (série)

\section{REFERÊNCIA BIBLIOGRÁFICA}

BERGAMASCHI, Diego Lopes. O Imaginário Ambiental, Práticas Espaciais e Expansão Urbana: Áreas limítrofes da ARIE JK - DF. (Monografia de Graduação), Curso de Graduação em Geografia, Universidade de Brasília, 2009. $47 \mathrm{f}$.

\section{CESSÃO DE DIREITOS}

NOME DO AUTOR: Diego Lopes Bergamaschi.

TÍTULO DA MONOGRAFIA: "O Imaginário Ambiental, Práticas Espaciais e Expansão Urbana: Áreas limítrofes da ARIE JK - DF"

GRAU/ANO: Bacharel/2009.

É concedida à Universidade de Brasília permissão para reproduzir cópias desta monografia e emprestar ou vender tais cópias somente para propósitos acadêmicos e científicos. O autor reserva outros direitos de publicação e nenhuma parte desta monografia de graduação pode ser reproduzida sem a autorização por escrito do autor. 
Dedico esse trabalho a pessoa responsável por todo meu desenvolvimento pessoal e profissional, minha mãe Ana Lúcia, mulher guerreira, corajosa, digna de muito orgulho e admiração. 
"Saber pensar o espaço, para nele se organizar, para nele se combater."

(LACOSTE, 2008). 


\section{LISTA DE FIGURAS}

Figura A - Evolução Demográfica do DF...................................................... 13

Figura B - Região Urbana, Poligonal ARIE JK e drenagem............................... 16

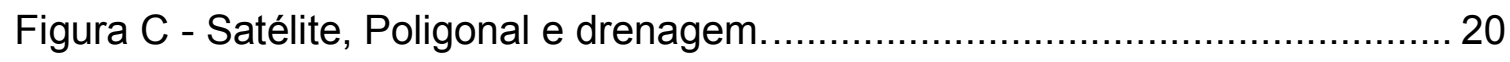

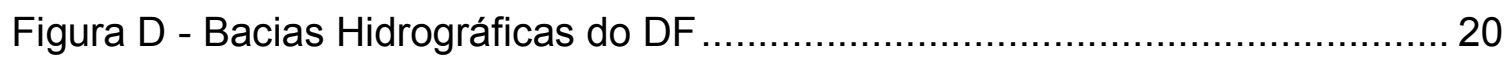

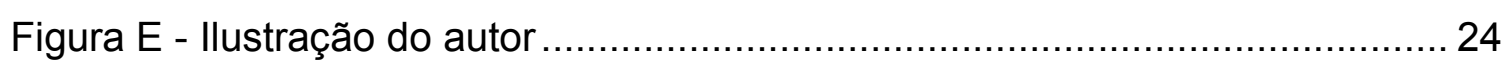




\section{LISTA DE ABREVIATURAS E SIGLAS}

PIC - PROGRAMA DE INICIAÇÃO CIENTÍFICA

CNPq - CONSELHO NACIONAL DE DESENVOLVIMENTO CIENTÍFICO E TECNOLÓGICO

APA - ÁREA DE PROTEÇÃO AMBIENTAL

ARIE - ÁREA DE RELEVANTE INTERESSE ECOLÓGICO

NOVACAP - COMPANHIA URBANIZADORA DA NOVA CAPITAL DO BRASIL

CEI - COMISSÃO DE ERRADICAÇÃO DAS FAVELAS 


\section{RESUMO}

O estudo do imaginário, procurando as representações que dão sentido e utilidade às práticas sociais que constroem o Meio Ambiente Urbano, pode nos oferecer relevantes constatações e compreensões. A gestão, o planejamento e as políticas públicas territoriais não serão capazes de atingirem, como o racionalismo técnico nos propõe, a eficácia no que tange um desenvolvimento equilibrado do espaço urbano. Não há instrumentos legais ou institucionais que possibilite isso enquanto não se buscar a totalidade que está presente tanto na materialidade quanto na sua subjetividade que se encontra na idéia das representações. A pesquisa nos possibilitou confirmar que o lugar, como lugar de vivência, de percepção constrói um imaginário ambiental que dialeticamente se opõe a imagem que os agentes hegemônicos fazem circular socialmente de uma cidade ambientalmente equilibrada. No entanto, há moradores na nossa área de estudo que reproduzem esta imagem, acreditando na boa qualidade de vida e a relacionando a um equilíbrio ambiental.

Palavras chave: Práticas Espaciais, Imaginário, Espaço Urbano, Discurso. 


\section{SUMÁRIO}

1 - APRESENTAÇÃO

2 - ESPAÇO URBANO, DISTRITO FEDERAL E REGIÃO DE INTERESSE ........ 11

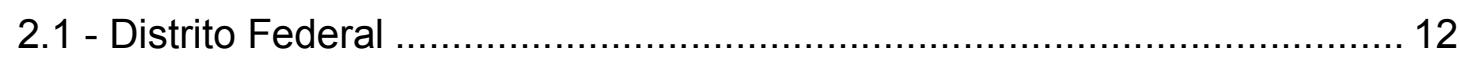

2.2 - Taguatinga

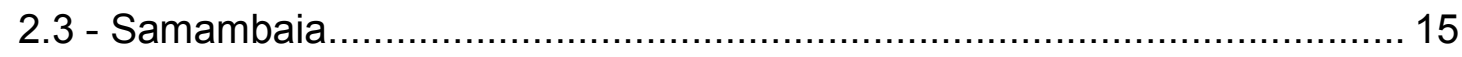

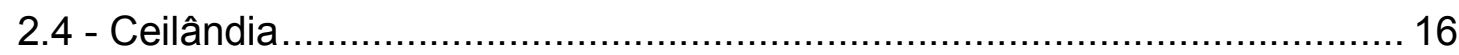

3 - UMA INTERSEÇÃO AMBIENTAL EM UM TERRITÓRIO OCUPADO POR MAIS DE UM MILHÃO DE PESSOAS: ARIE JK - DF ..................................... 18

4 - ASPECTOS E PROCESSO METODOLÓGICOS............................................. 21

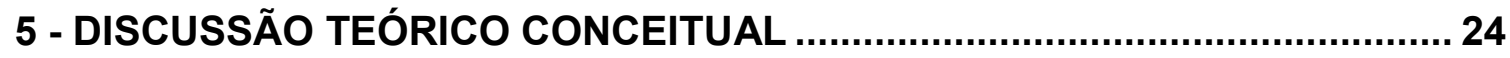

5.1 - Uma conceituação inicial ao tema: formas espaciais e simbólicas ........... 24

5.2 - A perspectiva da imagem ................................................................... 27

5.3 - Meio ambiente urbano e práticas sociais................................................ 29

5.4 - Representação Social e Meio Ambiente Urbano ……………………....... 30

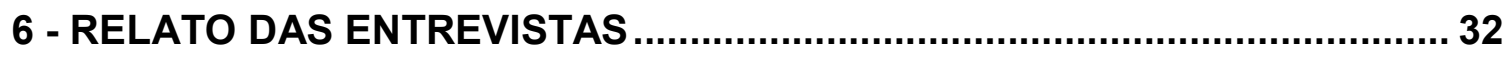

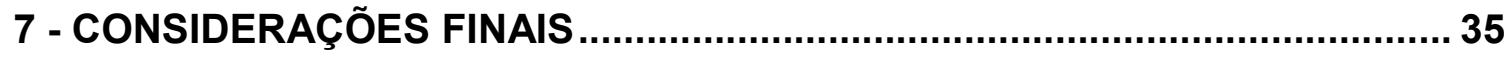

8 - REFERÊNCIAS BIBLIOGRÁFICAS ......................................................... 37

ANEXO A - BRASÍLIA NOS ANOS 60 E ATUALMENTE ..................................... 41

ANEXO B - TERCEIRO COLOCADO NO CONCURSO PARA O PROJETO DA

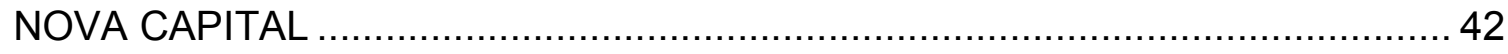

ANEXO C - SAMAMBAIA COM VISTA DA ARIE JK AO FUNDO ........................ 43

ANEXO D - TAGUATINGA COM VISTA DA ARIE JK AO FUNDO ...................... 44

ANEXO E - IMAGEM AÉREA DE CEILÂNDIA ………....................................... 45

ANEXO F - IMAGENS DE SATÉLITE DA ARIE JK E SUAS ÁREAS LIMÍTROFES

ANEXO G - SAÍDAS DE CAMPO NA ÁREA DE ESTUDO …..............................4 47 



\section{APRESENTAÇÃO}

Este trabalho nem início no Programa de Iniciação Científica - PIC da Universidade de Brasília e do Conselho Nacional de Desenvolvimento Científico e Tecnológico CNPQ. No entanto seus resultados também fazem parte de outro, de extensão do Departamento de Geografia e o do Decanato de Extensão dessa universidade desenvolvido sob o título "Práticas Sociais e Ambientais: estudo sócio-ambiental e urbano na APA do Descoberto/DF" com equipes coordenadas por diversos professores, dentre eles a professora e orientadora deste trabalho Marília Peluso. Nossa área de estudo faz parte da Área de Proteção Ambiental - APA citada à cima, sendo também uma unidade ambiental legalmente reconhecida e delimitada, a Área de Relevante Interesse Ecológico JK, que será mais bem explicitada posteriormente. O resultado deste trabalho também se tornou um artigo publicado tanto como resumo no $5^{\circ}$ Congresso de Iniciação Científica do Distrito Federal como trabalho completo nos Anais do II Seminário Nacional sobre Múltiplas Territorialidades, ambos apresentados também oralmente.

O estudo do espaço urbano de Brasília, com diversas variações de enfoque, sempre foi abordado de forma ampla por professores do Departamento de Geografia e outros pesquisadores da UnB. Dentre os enfoques, existe a que trabalha com questões urbanas que extrapolam a análise das formas materiais e espaciais, por acreditar que a problemática deve ser tomada também com a intensificação de estudos que valorizam os agentes, responsáveis pelas práticas espaciais, o sujeito, sua percepção e o conjunto de representações produzidas socialmente.

Para uma gestão mais satisfatória dos atores sociais envolvidos na questão da cidade e do meio ambiente é necessário ter como horizonte a urbanização acelerada nas grandes e pequenas escalas territoriais. No entanto só se pode pensar essa gestão resgatando a relação sociedade-natureza como construída historicamente e desta forma passível de mudanças, pois se dá objetivamente e subjetivamente. 
Trata-se de ações tanto objetiva de degradação ou conservação onde se encontram representações sociais que the dão sentido e utilidade. (PELUSO, 2003c).

Por isso, nos propomos a analisar a problemática do Meio Ambiente Urbano por meio do Imaginário Ambiental dos moradores e de suas representações das áreas limítrofes da ARIE JK. Se o território é construído por ações, o qual contém símbolos produzidos e circulados socialmente procuramos entender de que maneira o imaginário influencia as práticas espaciais e essa formação do espaço urbano.

O trabalho explora também a perspectiva de correlacionar o imaginário e suas representações, com a expansão urbana e a degradação do meio ambiente na área de estudo. Desta maneira o trabalho fará revisões conceituais e articulações importantes que permitam o melhor entendimento das dinâmicas objetivas e subjetivas produtoras do Meio Ambiente Urbano na região de estudo.

Partimos da hipótese de que imagens construídas ideologicamente tendem a se confrontar com as imagens do real, no lugar, no dia-a-dia, ou seja, nas vivências cotidianas de seus habitantes. Assim supõe-se que o mito de Brasília como cidade igualitária, eficiente e com boa qualidade ambiental se opõe ao imaginário de seus moradores, pois captam conflitos reais. Ou seja, o imaginário dos moradores de nossa área de estudo confrontaria dialeticamente com a imagem produzida pelos atores hegemônicos. 


\section{ESPAÇO URBANO, DISTRITO FEDERAL E REGIÃO DE INTERESSE}

"O espaço urbano é simultaneamente fragmentado e articulado: cada
uma de suas partes mantém relações espaciais com as demais, ainda
que de intensidade muito variável."

(CÔRREA, 2002: 07)

A área de estudo será disposta de forma que apresente como os espaços no Distrito Federal se constituem por meio de um processo e no qual as relações e influências entre eles são evidentes, assim como as suas distinções como localidade também são relevantes, relacionando sua história e momentos, com as da região de interesse do nosso trabalho que é formada por três regiões administrativas: Taguatinga, Ceilândia e Samambaia (ou como apresentou um morador: "TACESA") e que tem como interseção tanto territorial e ambiental a Área de Relevante Interesse Ecológico JK - ARIE JK.

Não é nosso objetivo construir um texto que aponte as diversas perspectivas de se entender e interpretar Brasília, as suas dinâmicas e complexidades mais a fundo, ou mesmo suas variabilidade e similaridades com outros espaços urbanos planejados. Trata-se de mostrar como se deu o processo de formação e consolidação de Brasília articulando ao surgimento de nossa área de estudo. Assim, serão apresentadas de forma fragmentada algumas caracterizações que serão novamente articuladas quando se abordar a ARIE JK como uma área de interseção, mas também de articulação para o nosso estudo. 


\subsection{Distrito Federal}

Dentro de objetivos desenvolvimentistas, idealizada e planejada sob as premissas do urbanismo modernista, nasce Brasília. Sua história de ocupação e evolução urbana nos apresenta características que vão se articulando ao resultado que produziu em nossa área de estudo. Um dos fatores que interferirão na questão ambiental e na qualidade de vida se refere exatamente a sua expansão urbana ligado ao crescimento rápido de sua população.

Rapidez que fica clara ao percebemos como evoluiu o número de habitantes entre os anos de 1957 a 1970 no Gráfico (1.1) a baixo:

Figura A 1.1

\section{Evolução Demográfica do DF}

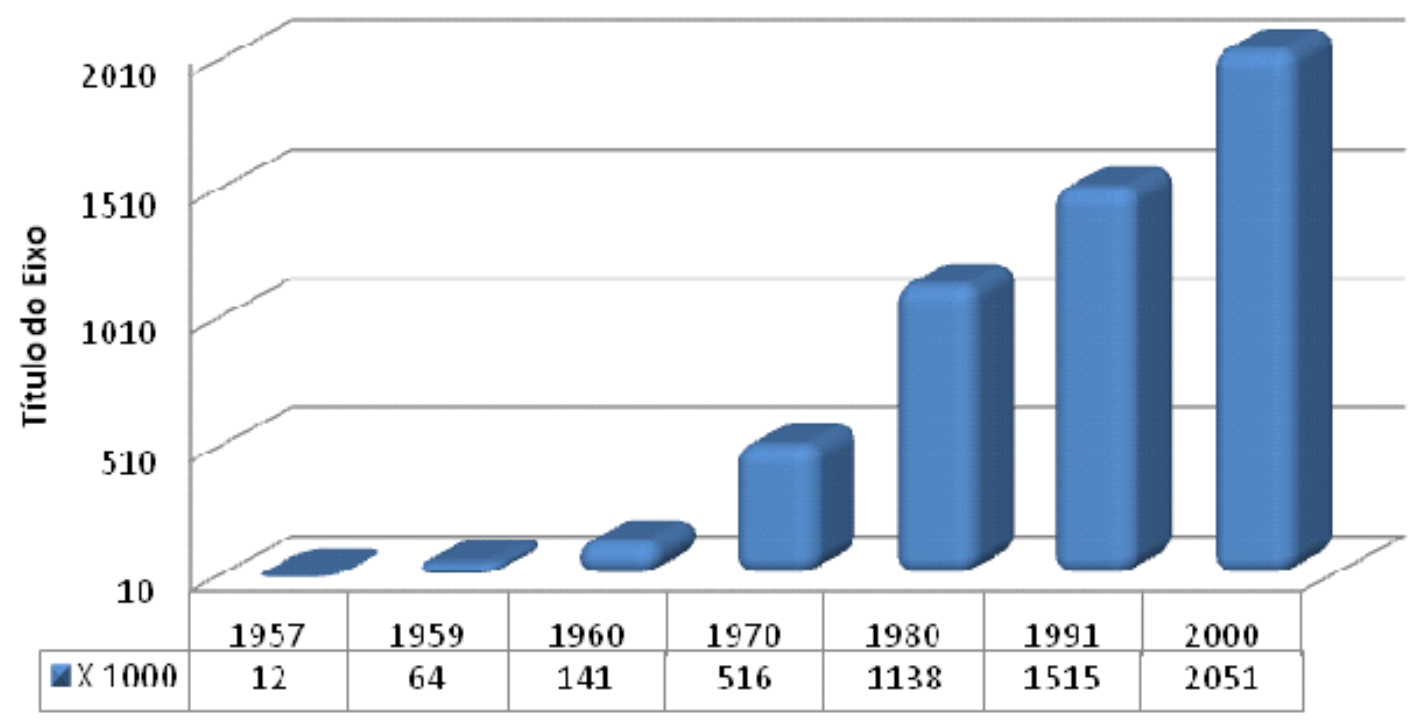

Fonte: PELUSO;PAVIANN . Revista Espaço e Geografia, 2003. 
O aumento populacional começa então a pressionar demandas diversas, entre elas a fundamental necessidade de território para sua instalação de novas moradias, 0 que começa a transparecer a instabilidade do planejamento. O que para PELUSO (2003a:10) a "negação do Brasil tal como era fragilizou imediatamente o projeto urbano de Brasília" onde "as soluções de planejamento propostas foram conservadoras, dentro do estilo de periferização e regulação da massa trabalhadora." No entanto, esse planejamento ineficaz não pode ser avaliado apenas sob a perspectiva de um erro dos especialistas, e sim como uma atitude de um agente produtor do espaço urbano, que responde a uma ideologia e representa grupos. Ou seja, tem que se pensar a evolução do espaço urbano como ação, e nunca como alguns propõe, como apenas um erro de planejamento ou mesmo como omissão do estado no Distrito Federal.

Segundo o planejamento inicial de Brasília, somente no ano de 2000 que a cidade alcançaria seus 500 mil habitantes, o que no ano de 1970 já tinha sido superado (tabela 1.1). Só quando a cidade atingisse esse número que seriam criadas de forma gradual as cidades satélites, que viria então a abrigar a população excedente. No entanto além do fluxo migratório a idéia do governo (GDF) de que os lotes deveriam ser vendidos aos poucos, esperando a valorização para que a venda da terra permitisse a implantação das infra-estruturas e serviços necessários criam um grande déficit habitacional no Distrito Federal, em especial nas classes de renda baixa e média (PELUSO, 1998:16)

A reformulação do planejamento inicial se dará muito antes do previsto, já que em 1958 fez-se necessária a criação da primeira cidade satélite, dentre as dezenas que ainda seriam criadas, Taguatinga. 


\subsection{Taguatinga}

A ocupação do território do qual hoje se encontra Taguatinga tem seus primeiros registros relacionados ao século XVIII e estimulados pela busca de metais preciosos e pela atividade Agropecuária. Em 1749 estabelece-se ali uma Sesmaria e as águas do Córrego Cortado, que faz parte da ARIE JK (figura B e C a seguir), que serviram

no atendimento as necessidades daquele povoamento. É também na beira desse córrego que se instala a sede da fazenda Taguatinga de Gabriel da Cruz Miranda.

Como se foi apresentado anteriormente, Taguatinga surge da necessidade de estabelecimento da população que já exercia enorme pressão sobre a cidade, sendo criada antes mesmo da Inauguração da cidade modernista e bem planejada. Uma das vilas que deram origem a cidade foi denominada Sarah Kubistschek, claramente uma escolha política, uma invasão sem nenhuma infra-estrutura onde tudo funcionava de maneira precária as margens da Rodovia Brasília-Anápolis.

A pressão para a implantação da cidade resultou na sua fundação no dia 5 de junho de 1958. Dez dias após o terreno ser determinado pela Novacap já haviam sido transferidas cerca de quatro mil pessoas, com instalação provisória de água e de transporte dos trabalhadores. Passados seis meses, Taguatinga tinha se transformado em uma realidade incontestável, pois nela já se via escolas, casa para professoras e estabelecimentos comerciais.

Hoje Taguatinga é uma cidade moderna, com diversos problemas semelhantes de outras brasileiras, e é considerada a mais independente do Plano Piloto. Já alcançou seus limites em crescimento horizontal, na década de 90 a evolução vertical da cidade era uma característica consolidada, surgindo atualmente empreendimentos de alto padrão, direcionados as classes abastadas. Seu planejamento inicial não 
valorizou a questão ambiental, onde posteriormente tentou-se fazer adequações que minimizassem os danos.

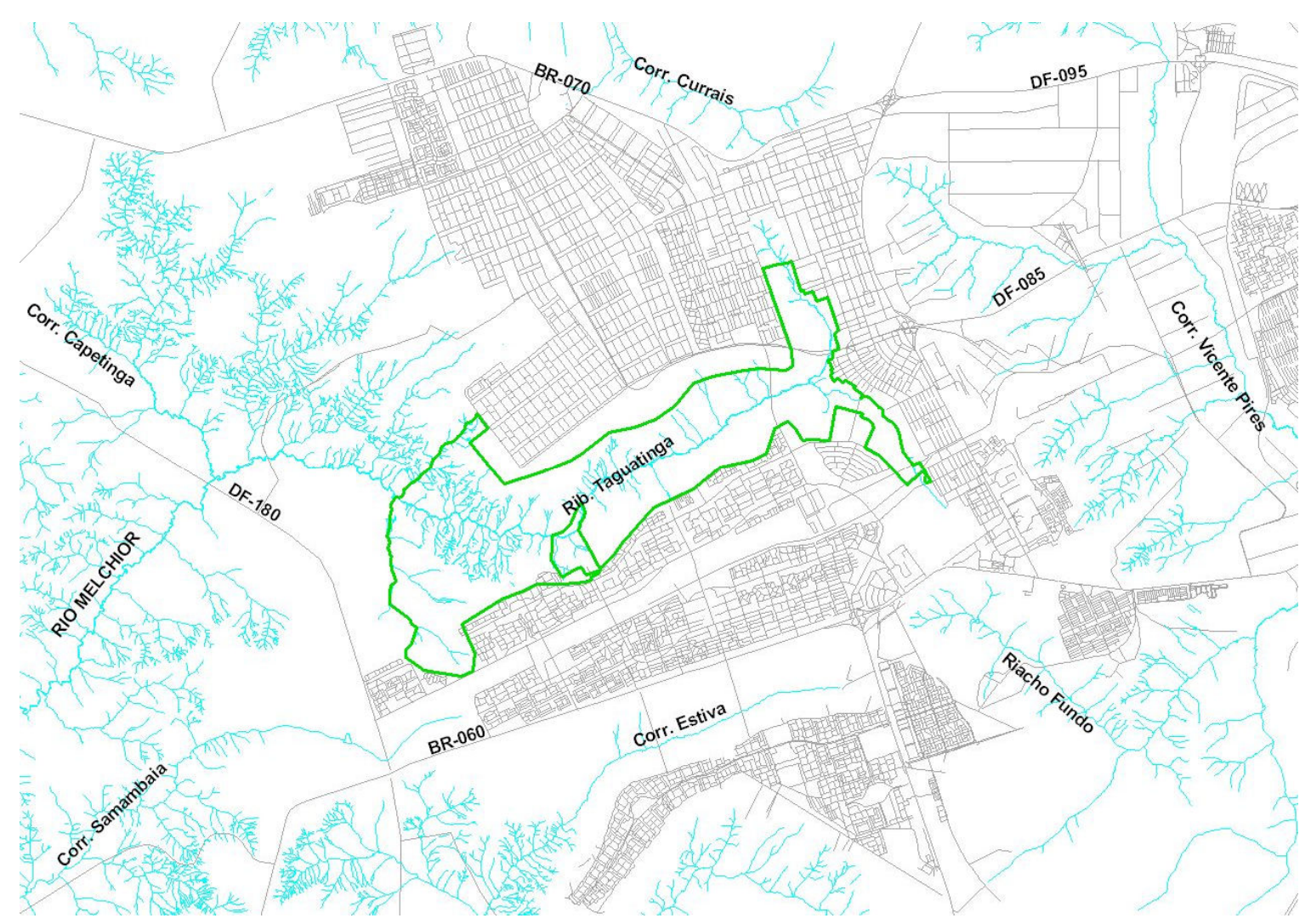

(Figura B: região urbana - escala cadastral, poligonal ARIE JK e drenagem. IBRAM - 2008)

\subsection{Ceilândia}

O Distrito Federal depois de apenas nove anos de sua inauguração contava com cerca de oitenta mil favelados. Com o agravamento dos problemas sociais fez-se necessário um Seminário para se discutir a questão e o favelamento foi apontado como o principal problema. É criado então, após ordem do Governador na época Hélio Prates à Secretaria de Serviços Sociais, um grupo de trabalho que mais tarde 
se transformaria em Comissão que daria origem a Campanha de Erradicação das Invasões - CEI que definiu quem seriam as famílias beneficiadas a ganhar um dos quase 18 mil lotes. Famílias vindas de invasões como do IAPI, das Vilas Tenório, Bernado Sayão e Colombo; dos morros do Querosene e o do Urubu dentre outros.

O programa ( $\mathrm{CEI}$ ) a cima que influenciará o nome da nova cidade, Ceilândia que oficialmente instalada no dia 27 de março de 1971. Onde finalmente, segundo PELUSO (2003a: 20), "o DF já estava organizado como um espaço diferenciado para abrigar as classes sociais contraditórias e reproduzir as relações sociais que deveriam ser superadas".

Com nove meses já estava concluída a primeira etapa do processo de transferência e ocupação das famílias, com as ruas abertas e seu conjunto urbanístico formando a figura de um barril, forma a qual logo se perderia, em virtude dos processos de expansão, tanto orquestrados pelo governo, assim como irregulares num processo intenso de grilagem que permanece até os dias atuais.

Importante considerar que boa parte dessas expansões sediadas nesta cidade se deram em áreas ambientalmente vulneráveis. Em áreas protegidas legalmente, direcionadas a produção agrícola ou mesmo com risco a saúde pública como ao redor da Usina de processamento de lixo da Ceilândia.

\subsection{Samambaia}

Criada para assentar famílias carentes, oriundas de invasões, cortiços e inquilinos de fundo de quintal, era formada inicialmente por chácaras pertencentes ao Núcleo 
Rural Taguatinga e eram ocupadas mediante concessão de uso que em parte foi desapropriada para receber a nova Região Administrativa (RA XII).

Também resultado do alto índice de migração a cidade foi criada oficialmente em 25 de outubro de 1989, no entanto seu processo de desapropriação e ocupação se deu um pouco antes. A professora Doutora do Departamento de Geografia da UnB nos oferece excelentes entendimentos da realidade e dinâmicas tanto do momento de implantação quanto no seu desenvolvimento. Em um artigo Marília PELUSO (2003a) nos apresenta o que lhe chamou atenção nesta cidade:

O que ressaltava em Samambaia era a ordem com que a remoção se processava, assim como a cooperação da população. Os caminhões chegavam, uns após outros, levantando nuvens de poeira, e deixavam à beira da estrada os removidos e seus pertences: o barraco desmontado, a mobília, o aparelho de televisão, malas, sacos e o desejo de possuir a casa própria (PELUSO, 2003a: 322).

Seu crescimento também se deu de forma impressionante, nela foram criados diversos bairros de expansão, atingidos limites em nenhum momento imaginados no planejamento inicial. Em seu território se mistura e se separa também diversas classes sociais, havendo desde expansões recentes direcionadas a famílias de baixa renda como área de lotes maiores denominado de Setor de Mansões. 


\section{UMA INTERSEÇÃO AMBIENTAL EM UM TERRITÓRIO OCUPADO POR CERCA UM MILHÃO DE HABITANTES: A ARIE JK}

A área estudada, apesar de interceder às três cidades apontadas e contextualizadas no texto, a ARIE JK pertence à Região Administrativa de Taguatinga é uma categoria de unidade de conservação de uso sustentável disciplinado pelo art. $16 \mathrm{da}$ Lei $n^{\circ} 9985 / 2000$, que tem por objetivo conciliar o uso humano com a preservação ambiental de ecossistemas importantes, inclusive para o ordenamento de uso e ocupação da terra e de outros recursos naturais indispensáveis às populações.

A ARIE JK (Imagem B acima e C abaixo) é uma unidade conservação de uso sustentável que no Distrito Federal, dentre outras funções sócio-ambientais, guarda a Área Rural Remanescente do Núcleo Rural de Taguatinga, as micro-bacias dos ribeirões Taguatinga e Cortado, tributários do rio Corumbá onde sua represa (ver Mapa 1: Bacias Hidrográficas do DF), que se encontra no limite territorial do DF e no estado de Goiás, é o principal fornecedor de água para o abastecimento do Distrito Federal. Além do Núcleo forma o parque a ARIE do Cortado e os parques Saburo Onoyama, Boca da Mata, Três Marias e sítios arqueológicos. 


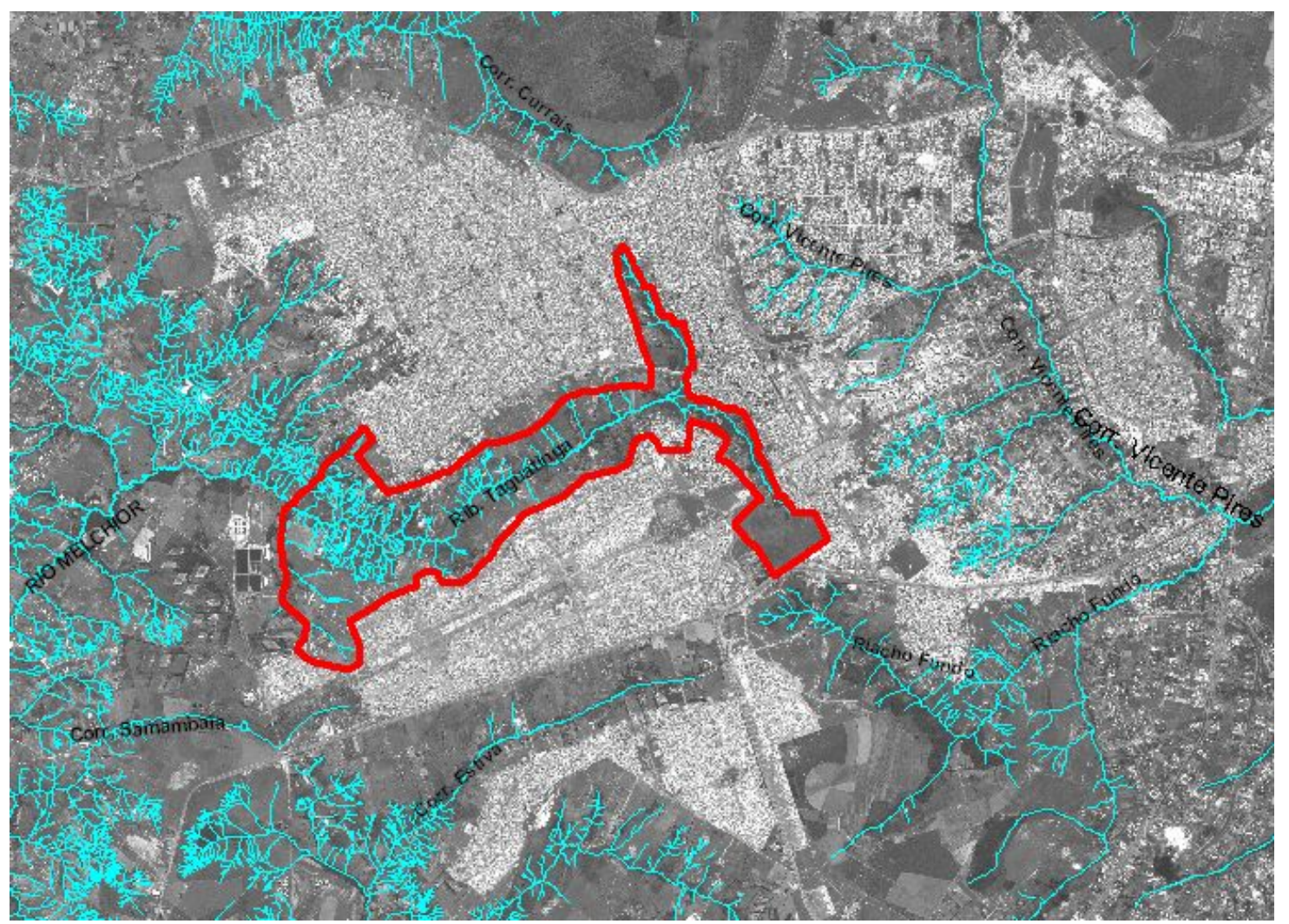

(Figura C b: satélite, poligonal da ARIE JK e drenagem. IBRAM - 2008)

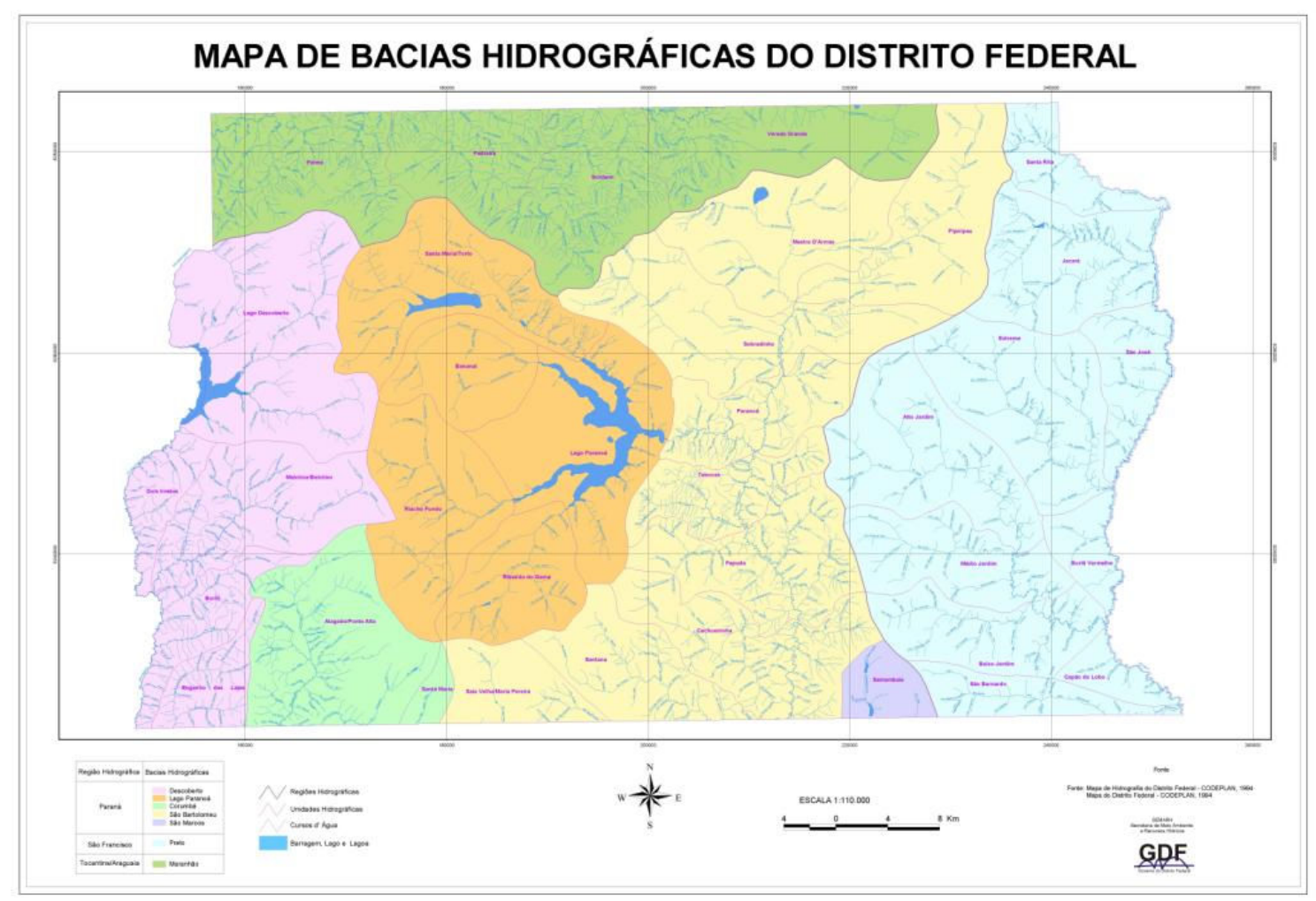

(Figura D 1.1 - Mapa de Bacias Hidrográficas) 
A ARIE JK enquanto instrumento de gestão do território e integração social, visa criar um espaço para promover o encontro entre produtores rurais da região, os grupos comunitários, o estado e as escolas, universidades e centros de pesquisa e extensão, a fim que se possa de forma mais eficiente resolver, identificar, e criar condições para resolver os problemas ambientais da região e disseminar a consciência ambiental e cidadã.

Como dito anteriormente, esse território de interesse ecológico que é assim determinado legalmente possui diversas características que demonstram sua importância quando ao que se tem dentro de sua poligonal estabelecida. No entanto o que nos traz ainda mais interesse é como está cercada hoje, pelas três consideráveis cidades e por um processo ainda vigente da expansão ilegal do tecido urbano, que como se sabe traz consigo danos ao meio ambiente em especial devido a ausência de Infra estrutura básica de saneamento e ainda pela má qualidade de vida de seus moradores, também considerado por nós uma questão ambiental.

Devido a essa peculiaridade, a localidade definida para aplicação dos questionários refere-se a antigas chácaras do Núcleo Rural Taguatinga que sofreram intenso processo de parcelamento irregular de suas terras e que se localizam dentro da poligonal da ARIE JK. Processo que ainda hoje, segundo alguns moradores em conversas informais no apontaram, ainda existe na região pressão de grileiros para que posseiros vendam suas terras para um posterior parcelamento. Acreditamos que essas condições, a dinâmica, a realidade e como se deu a evolução da ocupação urbana do espaço nessa região permite um estudo relevante quando ao Imaginário ambiental de seus moradores, suas representações e possíveis correlações quanto a suas práticas espaciais. 


\section{ASPECTOS E PROCESSOS METODOLÓGICOS}

A pesquisa social não significa uma sucessão de métodos e técnicas que bastaria ser aplicada como nos é apresentada, numa ordem verticalizada de imposição ao investigador social. Acreditamos ser uma escolha, onde os processos são estabelecidos de acordo com os objetivos e as especificidades de cada investigação.

Inicialmente aconteceram saídas de campo junto à disciplina Geografia Urbana I, organizadas junto à professora Marília Peluso, a Macro região de interesse deste trabalho nas cidades de Taguatinga, Samambaia e Ceilândia. O que nos permitiu uma aproximação as dinâmicas que estávamos nos propondo a pesquisar e que já exigiu uma pesquisa bibliográfica inicial.

Posteriormente saídas individuais ou com colegas se deram repetidas vezes para criar maior familiaridade à área de estudo e com o intuito de fazer observações ou obter informação sobre aquele território que nos apoiasse na pesquisa bibliográfica.

Foram obtidas informações, dados, cartas, mapas, croquis relacionados a área, ainda um acesso a denso material relacionado a métodos de entrevista e de análise, a artigos, livros, monografias, dissertações e teses. Conhecimentos expostos nesse trabalho e que se fizeram necessário no alcance de um salto qualitativo quanto ao entendimento das dinâmicas territoriais, assim como nas teorizações fundamentais e nas escolhas a serem aplicadas nos passos seguintes da pesquisa: as entrevistas, a análise e a discussão dos resultados. 
As entrevistas foram pensadas de acordo com as proposições feitas por GASKELL (2002). Por que no que tange a essa etapa metodológica, a pesquisa qualitativa não tem interesse em "contar" opiniões, mas sim explorar as distintas representações nos aspecto que nos propomos. O mesmo autor nos aponta também que aumentar o número de entrevistados não necessariamente aumenta a qualidade, por que:

(...) há um número limitado de interpelações, ou versões, da realidade. Embora as experiências possam parecer únicas ao indivíduo, as representações de tais experiências não surgem das mentes individuais; em alguma medida elas são resultado de processos sociais. (GASKELL, 20002: 70-71)

Estatisticamente a pesquisa aponta-se como totalmente aleatória e sem nenhuma razão probabilística, pois não houve nenhum tipo de controle do pesquisador quanto às pessoas que foram entrevistadas, já que a abordagem se dava conforme se encontravam moradores. A quantidade de entrevistados não tinha nenhuma razão matemática, mas sim uma amostra significativa para uma razão discursiva. Assim como PELUSO (1998: 17), "não nos interessava o indivíduo mitificado ou fetichizado dos grandes números abstratos, mas o resgate do sujeito-falante em e na sociedade, desvendando seus discursos e mostrando suas ambigüidades" (Veja ilustração acima: Imagem C). Estas entrevistas se deram tanto individualmente quanto com a professora orientadora deste trabalho e colegas do Projeto de extensão "Práticas sociais e ambientais: estudo sócio-ambiental e urbano na APA do Descoberto - DF" o qual participávamos paralelamente. 


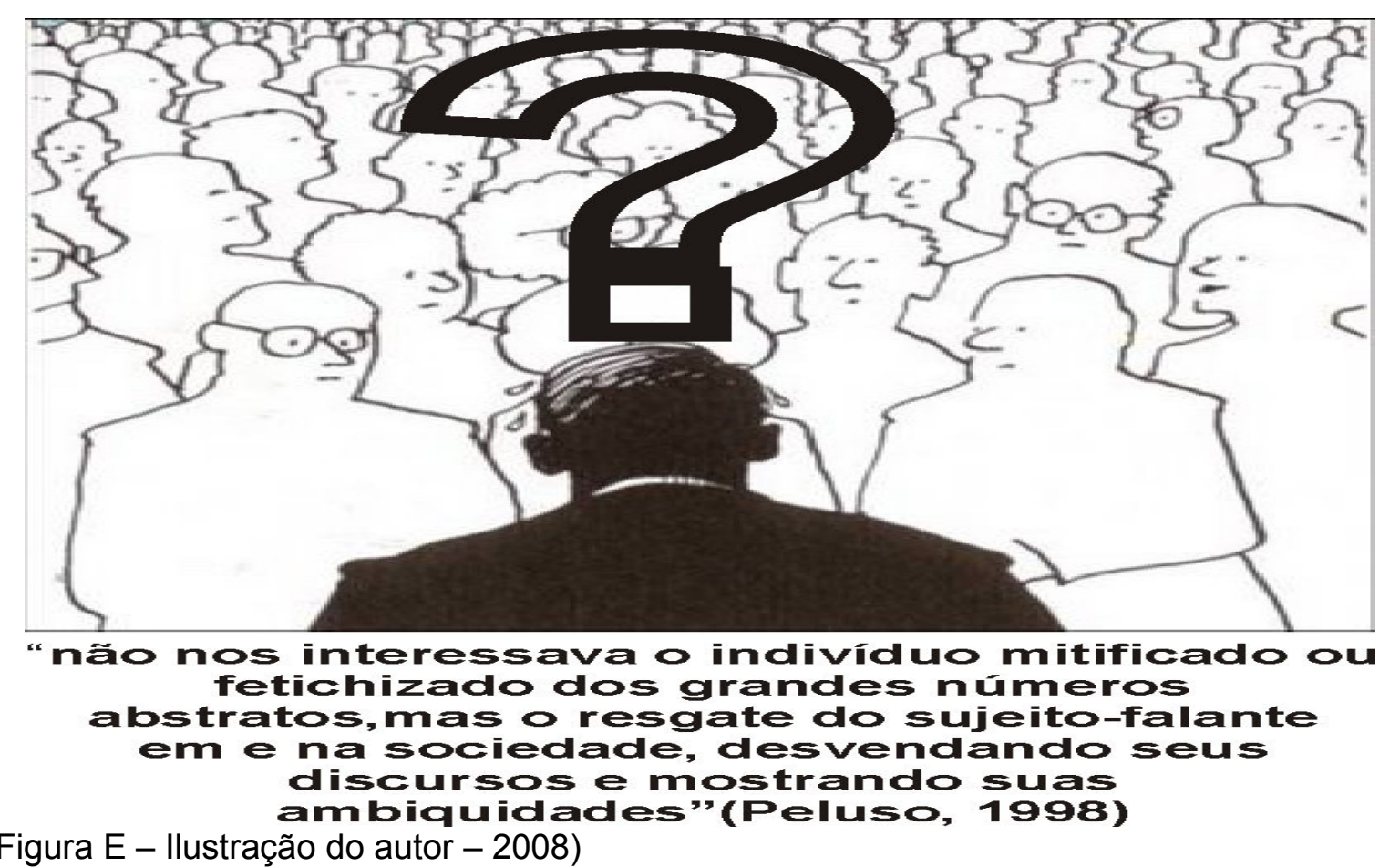

(Figura E - llustração do autor - 2008)

Depois de completa a quantidade de entrevistas que nos dava uma razão discursiva, resultando em algumas horas de entrevista, fez-se as transcrições que permitiram então seu estudo segundo as perspectivas de uma "análise de discurso". Discurso tomado como "palavra em movimento, prática de linguagem: com o estudo do discurso observa-se o homem falando". "Procurando compreender a língua fazendo sentido, enquanto trabalho simbólico, parte do trabalho social geral, constitutivo do homem e de sua história", compreendendo-se a produção de sentidos por/para os sujeitos. (ORLANDI, 2005: 254-255).

Analisando os discursos construiu-se o imaginário dos moradores das áreas limítrofes a ARIE JK e suas representações que nos permitiu então, analisar toda a pesquisa, os resultados obtidos e relacioná-los aos interesses iniciais, permitindo fazer as considerações adequadas. 


\section{DISCUSSÃO TEÓRICO - CONCEITUAL}

\subsection{Uma conceituação inicial ao tema: Formas Espaciais e Simbólicas}

As formas são resíduos de estruturas que foram presentes no passado e também se configuram no presente, pensá-la significa fazer recortes onde seja possível construir a união de suas importantes dimensões: o espaço e o tempo. Necessitamos, então, especular a forma em sim e sua possibilidade de análise como representação de uma realidade e até mesmo como caminho para que se alcance a capacidade de prever, ou seja, indagar, refletir e planejar.

O professor RIBEIRO (2006) refere-se ao método o materialismo históricogeográfico, nos dizendo da necessidade de "atinar à geografia das formas espaciais de reprodução da existência humana no tempo, pois todas as sociedades deixam suas pegadas no espaço". Se então estas "pegadas" existem, precisamos ultrapassar o mistério da forma, a forma particular a que Gramsci se referia e buscar a construção do método capaz de entendê-lo (SANTOS, 1997:69). Este autor também nos oferece excelente contribuição, quanto a produção do espaço, que nos auxilia neste entendimento:

(...) o espaço portanto é um testemunho, ele testemunha um momento de um modo de produção pela memória do espaço construído, das coisas fixadas na paisagem criada. Assim o espaço é uma forma, uma forma durável, que não se faz paralelamente a mudanças de processos; ao contrário, alguns processos se adaptam as formas para inserir dentro delas. (SANTOS, 1980: 138). 
Assim, o espaço nos apresentará formas espaciais que serão resultado de dois processos, a inércia e a refuncionalização, fazendo com que as formas criadas no passado (presente) sejam projetadas no presente (futuro). Para isso a todo o momento precisamos tomar as precauções que nos evite especulações incongruentes e inconseqüentes (CORREA, 2007: 1).

O espaço, sua produção e dinâmicas possuem singularidades que precisamos entender de maneira que nos facilite o entendimento. O professor Godoy (2004), a luz de HAVEY (1993), nos oferece um bom exemplo prático de análise sistêmica onde as formas espaciais se tornam bastante evidentes no processo de introdução de novos capitais em dada região:

(...) de modalidade flexíveis de acumulação e gerenciamento, supõe a busca de vantagens comparativas que se materializam em formas espaciais novas ou na reutilização de formas preexistentes, proporcionando, em escala local-global, a intensificação dos fluxos de bens e informações. As vantagens comparativas podem apresentar-se momentâneas ou transitórias e gerar formas espaciais cujas funções serão dissolvidas na medida em que as vantagens localizacionais tornarem-se 'rugosidades' para a reprodução do capital. (GODOY, 2004:37).

$\mathrm{O}$ que nos permite salientar e que alguns estudos ressaltaram na década de $70 \mathrm{e}$ 80, de que certas estruturas resultantes da fase de industrialização fordista se encontravam em processo de dissolução ou aniquilamento, sendo que estas formas foram substituídas por novas formas e novas funções exigidas pelo novo modelo emergente, o de acumulação flexível (GODOY, 2004).

Concomitante a tudo isso que se sabe quanto à capacidade que os estudos das formas, especificamente das formas espaciais, possuem no entendimento da realidade e na possibilidade de projetar o futuro, podemos inserir as formas 
simbólicas como um conceito que se une as demais dando maior fortalecimento de prováveis resultados, nos dando assim, mais confiança nos resultados obtidos. De tal maneira que precisamos mostrar o que se refere formas simbólicas, suas conceituações e tentar construir a ponte que a relaciona com formas espaciais. Isso tudo preliminarmente.

O aspecto mais valorizado por nós quanto às formas simbólicas se refere a que medida seu entendimento nos permite perceber as práticas ou ações de indivíduos, grupos e determinados frações da sociedade. Se formas simbólicas são, como nos fala THOMPSON (1995: 78-79), uma variada gama de ações e falas, imagens e textos, reconhecidos por seus produtores e por outras pessoas como construções significativas, podemos adequá-la como conhecimento prático e relacioná-lo as formas espaciais. O mesmo autor considera que o sentido mobilizado pelas formas simbólicas e elas próprias são elementos constituintes da realidade social e ainda participam ativamente na criação e na manutenção das relações entre pessoas e grupos.

A professora da UnB Lúcia Cony F. Cidade nos dá um exemplo da apropriação das formas simbólicas no entendimento da produção do espaço. Ela usufrui de uma parte significante destas formas, a imagem, como meio de entendimento da organização do espaço relacionado com os corpos d'água em cidades, aplicado ao exemplo do Lago Paranoá em Brasília, Distrito federal. Ela nos diz que existe um papel ativo da mente na conduta das pessoas, e que logo o entendimento desta imagem nos permite entender a maneira como se age na produção do espaço (CIDADE, 2005).

Ou seja, entendermos a mentalidade urbana, nos permite extrapolar o mistério das formas simbólicas e sermos capazes de formular questões ao espaço na tentativa de sermos cada vez mais eficazes no entendimento dos processos, suas formações e caminhos prováveis que ele nos apresenta. Sintetizada na conclusão de que 
diferentes funções simbólicas incidem sobre as práticas sociais e assim alteram a produção social do espaço.

\subsection{A perspectiva da imagem}

Sendo uma das perspectivas abordadas na pesquisa, o imaginário ambiental de moradores, faz-se fundamental uma breve apreciação de como se configuram algumas possibilidades do entendimento do conceito de imagem. Essa terminologia já vem sendo evidenciada em alguns trabalhos referentes a problemática urbana, por que as pessoas constroem imagens de suas cidades e dos lugares que vivem. $\mathrm{E}$ mais, por que a "uma determinada imagem são atrelados não somente qualidades icônicas de uma idéia imprecisa como também valores que permitem compreender e se situar em relação a mesma" (MONTEIRO, 1996: 908).

Quando o imaginário passa a ser coletivo, sensibiliza as pessoas, tocam as emoções, vontade e desejos, assim, um imaginário coletivamente proposto é capaz de transformar o real, criando hipóteses que geram critérios para atuação e identificação de ações a serem desenvolvidas (CARIOLANO, 2001).

Estudos no exterior e no Brasil são diversos quanto o papel da imagem e suas implicações. Inicialmente, destaca-se um autor que se tornaria uma importante referência nesta discussão, KENNETH BOULDING (1969) que estabelece alicerce para o entendimento da dinâmica de sua formação e quais são as perspectivas de uso da imagem. Não é considerado pelo autor as imagens como algo que leve a verdade ou que valide alguma. Apenas considerando-a como um conhecimento e neste caso subjetivo (CIDADE, 2003:159). 
Um importante autor que enriqueceu a idéia de imagem atrelada ao espaço foi o filósofo Gaston BACHELARD (1972), quando ele publicou seu estudo o qual apontava o tratamento do espaço na poesia e com grande valorização a idéia de imagem. Considerando a distinção entre uma mente realista e crítica, o qual segundo ele este não aceitaria imagens não condicionadas e aquele sentiria a necessidade de confrontá-las com a realidade. (CIDADE, 2003:160).

Outro marco foi quando, em 1960, KEVIN LYNCH (1971) no estudo do espaço urbano nos ofereceu o estudo da imagem ambiental como um dos aspectos atinentes ao espaço urbano. Considerava que a relação entre o observador e seu ambiente consistia em uma via de mão dupla, ou seja, cria-se uma relação de influência mútua. (CIDADE, 2003:160). Estudos como de JUDELET e MILGRAN (1977) o qual mostram a imagem social de Paris ou o estudo de PAILHOUS (1984), são todos exemplos de como são ricos os estudos urbanos que tem aporte no uso das imagens. Ou como nos alerta MOSCOVICl (1976) "o espaço urbano considerado a matéria bruta de vida cotidiana é basicamente percebido, compreendido e determinado pelas representações mentais e de forma alguma é tão determinado ou organizado como costumávamos pensar".

No Brasil e em Brasília estudos diversos apontam nessa possibilidade, nesta há em especial capítulos publicados em livros organizados por Aldo Paviani, como os de CIDADE $(2000 ; 2003 ; 2005)$ na relação "Espaço desigual, imagem da cidade e turismo em Brasília"; "Qualidade ambiental, imagem da cidade e práticas sócioespaciais", em "Ideologia, imagem ambiental e organização do espaço urbano" (explicitado por nós quando falamos de formas espaciais e simbólicas) e também de MACHADO e MAGALHÃES (1985). Os trabalhos já produzidos consolidam um bom arcabouço teórico para o entendimento do estudo da imagem no estudo da questão do meio ambiente urbano na cidade. 


\subsection{Meio Ambiente Urbano e práticas sociais}

A forma como Brasília ocupou seu território e seus resultados ao meio ambiente muito pouco representam a imagem que os estado tenta impor de equilíbrio e eficiência. Uma realidade é que um dos problemas mais sérios de Brasília refere-se a apropriação de terras públicas por particulares, cujo o resultado foi a destruição do meio ambiente.

Um espaço urbano onde atores sociais agem na procura de atender a seus benefícios individuais e de seu grupo e onde a gestão do território se apresenta insatisfatória torna a questão ainda maior. PELUSO (2003) nos demonstra a que ponto a intensificação desse movimento se relaciona com as práticas:

O comportamento predatório que caracteriza a ocupação territorial da capital do país não é algo aleatório nem característico, mas uma face do ímpeto destrutivo em relação à natureza que se tem acelerado grandemente, de tal maneira que as práticas sociais, em alguma escala, revelam-se predatórias (PELUSO, 2003c: 181).

Entende-se meio ambiente como um habitat socialmente criado, configuração de um meio físico modificado pela ação humana (JACOB, 1995) e acreditamos que o entendimento da questão ambiental não pode ser configurado apenas na valorização do impacto objetivo das condições reais sobre os indivíduos, mas também de que maneira isso se relaciona coma vivência social e valores culturais agem na construção dos mesmos impactos.

Num contexto em que vivemos uma degradação permanente do meio ambiente e também de seu ecossistema maior, a reflexão quanto as práticas sociais necessitam sempre de um relacionamento com o entendimento dos atores envolvidos, dos 
grupos e da organização social para que se possa entender os desdobramentos e alternativas que nos direcionem a uma perspectiva de sustentabilidade.

\subsection{Representação Social e Meio Ambiente}

Acreditando que quando tratamos de imaginário estamos nos referindo a um sujeito coletivo, se instaura a necessidade de trazer a noção de Representação Social ao nosso estudo, já que como está exposto em PELUSO (2003c: 183): "as representações sociais se encontram na encruzilhada entre o indivíduo e a sociedade e JODELET (1985) desenvolve a idéia de que a sociedade fala, mas o indivíduo emite o discurso, permite-se pensar o subjetivo individual e voltar ao campo do geral e do objetivo, num movimento dialético muito produtivo".

A vivência de cada indivíduo está claramente relacionada ao seu lugar, mas também à sua sociedade e as práticas sociais nelas existentes. De tal maneira que isso possibilita uma "consciência de si e do grupo que são articulados em conjuntos inteligíveis que podem ser entendidos como Representação Social" (PELUSO, 1998: 113).

Existe então uma realidade, que é física e social, que se torna inteligível por meio da efetivação de um corpus organizado de conhecimento e também de uma das atividades psíquicas. Libera-se então o poder da imaginação quando inseridos num grupo ou numa ligação cotidiana de trocas. (MOSCOVICI, apud PELUSO, 1998: 113). 
O processo de pensar, segundo a perspectiva da representação social, não acontece em um contexto abstrato, as pessoas ouvem pensam e comunicam suas idéias, soluções e representações nas ruas, praças, bares. É possível dizer que boa parte das representações tem um componente ambiental da mesma maneira que as relações sociais das quais emergem. Há também, evidente, representações sociais que transcendem lugares e se referem mais a determinadas classes sociais ou a uma cultura específica (MONTEIRO, 1996:910).

A professora Marília PELUSO (2003c) em seu texto que reflete sobre as representações sociais e o ambiente urbano nos demonstra a vantagem de fazer essa relação:

entender a problemática do meio ambiente utilizando-se das representações sociais significa construí-la como decorrente de um imaginário dinâmico, enraizado socialmente, cujo jogo dirige o olhar e conhecimento do sujeito sobre o mundo que o cerca (PELUSO, 2003c: 182).

Torna-se claro que o uso das representações para o entendimento do meio ambiente urbano é possível e cada vez mais sólido, mas não só, por que essas construções nos encaminham ao esclarecimento de como pode ser dar a relação do imaginário ambiental com as práticas sócio-espaciais. 


\section{RELATO DAS ENTREVISTAS}

Do volume de entrevistas que obtivemos durante a pesquisa, possibilitando a construção de uma análise inicial quanto ao imaginário ambiental dos moradores das áreas limítrofes a ARIE JK, relataremos algumas representações que nos ficaram evidentes e que consideramos como significativas para contribuir com os objetivos para os quais essa pesquisa se propôs.

A imagem construída pelo atores hegemônicos, de Brasília como uma cidade de qualidade e equilíbrio ambiental cria um estado de contradição quando é evidenciada a imagem ambiental percebida. Os moradores da área estudada apresentam uma representação que se opõe a essa perspectiva, criando um discurso onde o mito de Brasília se desfaz quando dialogado com as percepções cotidianas. No entanto como poderemos perceber na fala a seguir, existe também a reprodução da imagem que circulada socialmente de equilíbrio no que se refere à qualidade de vida:

"Qualquer lugar em Brasília é bom. (...) Acho que qualquer cidade satélite de Brasilia tem boas qualidades de vida"

(Morador do parcelamento da chácara 26)

A idéia de que o tempo de moradia, ou seja, de pertencimento aquele lugar definiria a responsabilidade com o meio ambiente, cria duas percepções: dos que moram mais e menos tempo nesse lugar. Para aqueles o tempo é fator importantíssimo, por que se cria uma afinidade e respeito com o seu meio e com as pessoas. Contudo, aqueles com menos tempo tendem a negação desta idéia, considerando irrelevante para definir responsabilidade e valorizando a questão como relacionado apenas a "personalidade", como está expresso no seguinte discurso: 
“(...) acho que responsabilidade não quer dizer mais tempo de residência no lugar, responsabilidade é uma questão de pessoa, de berço."

(Morador do parcelamento da chácara 27)

A degradação, dependendo da ótica de algumas pessoas a degradação do meio ambiente pode contribuir para a melhora de sua vida por meio da manutenção de sua propriedade naquele lugar. Uma proprietária de uma chácara nos aponta uma prática no parcelamento da chácara vizinha:

“(...) no projeto do loteamento eles colocaram uma estrada em cima da nascente (...) eles projetaram isso, mas não conseguiram de uma vez só, eles estão fazendo progressivamente, todo ano vai apertando."

E por que essa prática acontece também nos é explicitado. Trata-se de uma atitude de degradar para legalizar:

"Por que se essa nascente ainda estiver com força na época que for feita a regularização, todos os que estão ao redor correm o risco de serem retirados."

Um imagem homogênea nos discursos refere-se a relação dessa prática de parcelamento irregular do território e a conservação do meio ambiente. O imaginário exposto é de que essa prática é nociva sim ao meio ambiente, no entanto todos os entrevistados dizem ter comprado seus lotes ou casas de pessoas que não os grileiros, o que para eles significa uma salva guarda de suas responsabilidades quanto a esse processo. A culpa recai aos outros e aos que permitiram o início dessas práticas. 
Mas como nos alerta uma proprietária de chácara, ainda existe pressão de grileiros na região para o parcelamento de mais chácaras, e o crescimento da cidade e seus problemas ambientais urbanos têm exprimido o Núcleo Rural Taguatinga e nos diz:

"Uma situação muito desconfortável, essa morosidade em resolver esse problema." 


\section{CONSIDERAÇÕES FINAIS}

A possibilidade de estudar a problemática do espaço, em especial a questão do meio ambiente urbano incorporando a subjetividade se mostrou importante, mas não só, demonstrou-nos necessária. Não cabe mais pensar a sociedade apenas com seus números abstratos, com suas caracterizações materiais e objetivas, tem que se construir um conhecimento que ultrapasse o discurso, apenas, da interdisciplinaridade. É necessário estudamos as práticas sociais e o ambiente, espera-se que se torne ação normal e valorizada nas pesquisas sociais e no ambiente universitário.

O estudo do imaginário, procurando as representações que dão sentido e utilidade às práticas sociais que constroem o Meio Ambiente Urbano, pode nos oferecer relevantes constatações e compreensões. A gestão, o planejamento e as políticas públicas territoriais não serão capazes de atingirem, como o racionalismo técnico nos propõe, a eficácia no que tange um desenvolvimento equilibrado do espaço urbano. Não há instrumentos legais ou institucionais que possibilite isso enquanto não se buscar a totalidade que está presente tanto na materialidade quanto na sua subjetividade que se encontra na idéia das representações.

A pesquisa nos possibilitou confirmar que o lugar, como lugar de vivência, de percepção constrói um imaginário ambiental que dialeticamente se opõe a imagem que os agentes hegemônicos fazem circular socialmente de uma cidade ambientalmente equilibrada. No entanto, há moradores na nossa área de estudo que reproduzem esta imagem, acreditando na boa qualidade de vida e a relacionando a um equilíbrio ambiental. 
É importante evidenciarmos, que constatamos variações diversas quanto a como as pessoas percebem o meio ambiente, que imagens fazem e como isso reflete em suas práticas sociais. Ou seja, o lugar que vive, sua história, seus relacionamentos interpessoais, aquilo que te envolve e que faz parte da sua constituição, influencia nas construções simbólicas que possui, nas representações que carrega, influenciando em sua relação de troca com o meio, Ihe dando a utilidade e o sentido, o que permite a manutenção do ciclo permanente de relacionamento sociedademeio ambiente. Acreditamos também que o estudo do imaginário em outros lugares ou regiões para fins de comparação e correlação permitira um maior entendimento de como se processa essas relações, e de que maneira configura as práticas sociais no território. 


\section{REFERÊNCIAS BIBLIOGRÁFICAS}

CARIOLANO, Luzia Neide M.T. "O real e o imaginário nos espaços turísticos". In: ROSENDAHL, Zeny e CORREA, R.L. (orgs.). Paisagem, imaginário e espaço. Rio de Janeiro, EdUERJ, 2001.

CIDADE, Lúcia Cony F. ." Qualidade ambiental, imagem de cidade e práticas socioespaciais". In: Aldo Paviani; Luiz Alberto de Campos Gouvêa. (Org.). Brasília:controvérsias ambientais. Brasília: Editora da Univiersidade de Brasília, 2003, v. 1, p. 181-196.

CIDADE, Lúcia Cony F. "Ideologia, Imagem ambiental e Organização do espaço urbano". In: Encontro Nacional da Anpege, 6, 2005, Fortaleza. Anais ... Fortaleza: Anpege; Universidade Federal do Ceará - UFC; Universidade Estadual do Ceará UECE, 2005. CD-ROM, 16p.

CORRÊA, Roberto Lobato. O espaço Urbano. São Paulo: Ática, 2002.

CORRÊA, Roberto Lobato. "Perspectivas da urbanização brasileira - uma visão geográfica para o futuro próximo". In: X Simpósio Brasileiro de Geografia Urbana SIMPURB, 2007, Florianópolis. Anais ... Florianópolis: SIMPURB; Universidade Federal de Santa Catarina - UFSC, 2007.CD-ROM.

GASKELL, G.. "Entrevistas individuais e grupais". In: GASKELL, G., BAUER, M.W. Pesquisa Qualitativa com Texto, Imagem e Som. Um manual prático. São Paulo: Editora Vozes, 2002. 
GODOY, Paulo. "Uma reflexão sobre a produção do espaço". Estudos Geográficos, Rio Claro, 2(1): 29-42, junho-2004 (ISSN 1678-698X) www.rc.unesp.br/igce/grad/geografia/revista.htm

HARVEY, D. A Justiça social e a cidade. Tradução Armando C. da Silva. São Paulo: Hucitec, 1980.

JACOBI, P.. "Moradores e meio ambiente na cidade de São Paulo". Revista de Administração Municipal. 42 (216): 26-50. Rio de Janeiro: IBAM, 1995.

LACOSTE, Yves. A Geografia - Isso serve, em primeiro lugar para fazer a guerra. Campinas, Papirus: 2008.

MACHADO, Lia Zanotta, MAGALHÃES, Themis Quezado de. "Imagens do espaço: imagens da vida" In: PAVIANI, Aldo (org.) Brasília, ideologia e realidade; espaço urbano em questão. São Paulo: Projeto, 1985, p. 191 - 214.

MONTEIRRO, Circe Maria Gama. "Representações sociais da cidade: do imaginário ao real". In Encontro Nacional da ANPUR (6: 1955: Brasília) Modernidade, exclusão e a espacialidade do futuro: anais .../ organizado por Ricardo L. Farret - Brasília: ANPUR, 1996, P. 908-916.

MOSCOVICl, S. A representação social da Psicanálise. Rio de Janeiro: Ed Zahar, 1978.

ORLANDI, Eni Puccinelli. Análise do Discurso: princípios e procedimentos. Belo Horizonte: Editora Pontes, 2005. 
PAVIANI, A. . "Geografia Urbana do Distrito Federal: evolução e tendências". Espaço e geografia, Brasília, v. 6, n. 2, p. 30-52, 2003.

PELUSO, M. L.. O morar na constituição subjetiva do espaço urbano. as representações sociais da moradia na cidade-satélite de Samambaia/DF. Tese (Programa de Psicologia Social) - Pontifícia Universidade Católica de São Paulo (PUC/SP), 1998.

PELUSO, M. L.. "O Papel das representações do comprar a casa na identificação dos problemas habitacionais".. In: Paviani, A. (Org.). Gestão Urbana: Conflitos e Cidadania. Brasília: Editora UnB, p. 111-132, 1998.

PELUSO, M. L.. "Brasília: do mito ao plano, da cidade sonhada à cidade administrativa". Espaço e geografia, Brasília, v. 6, n. 2, p. 7-34, $2003 a$.

PELUSO, M. L.. "O potencial das representações sociais para a compreensão interdisciplinar da realidade: Geografia e Psicologia Ambiental". Estudos de Psicologia (Natal), Natal, v. vol 8, n. núm 2, p. 321-328, 2003b.

PELUSO, M. L.. "Reflexões sobre ambiente urbano e representações sociais". In: Paviani, A.; Gouvêa, L. A. C.. (Org.). Brasília: controvérsias ambientais. Brasília: Editora da Universidade de Brasília, p. 181-196, 2003c.

RIBEIRO, Júlio César. A geografia das formas espaciais de reprodução da existência humana ao longo do tempo á luz do materialismo histórico -geográfico. 2006. 303f. Tese (Doutorado em geografia) - Programa de Pós-graduação em 
Geografia, Instituto de Geociências, Universidade Federal Fluminense - UFF, Rio de Janeiro, 2006

SANTOS, Milton. Espaço e Sociedade. Petrópolis: Vozes, 1980.

SANTOS, Milton. Técnica, Espaço, Tempo: Globalização e o Meio Técnico-Científico Informacional. São Paulo: Editora Hucitec, 1997.

THOMPSON, Jonh B. Ideologia e cultura moderna: teoria social critica na era dos meios de comunicação de massa. Petrópolis: Vozes, 1995. 
ANEXO A - BRASÍLIA NO ANOS 60 E ATUALMENTE
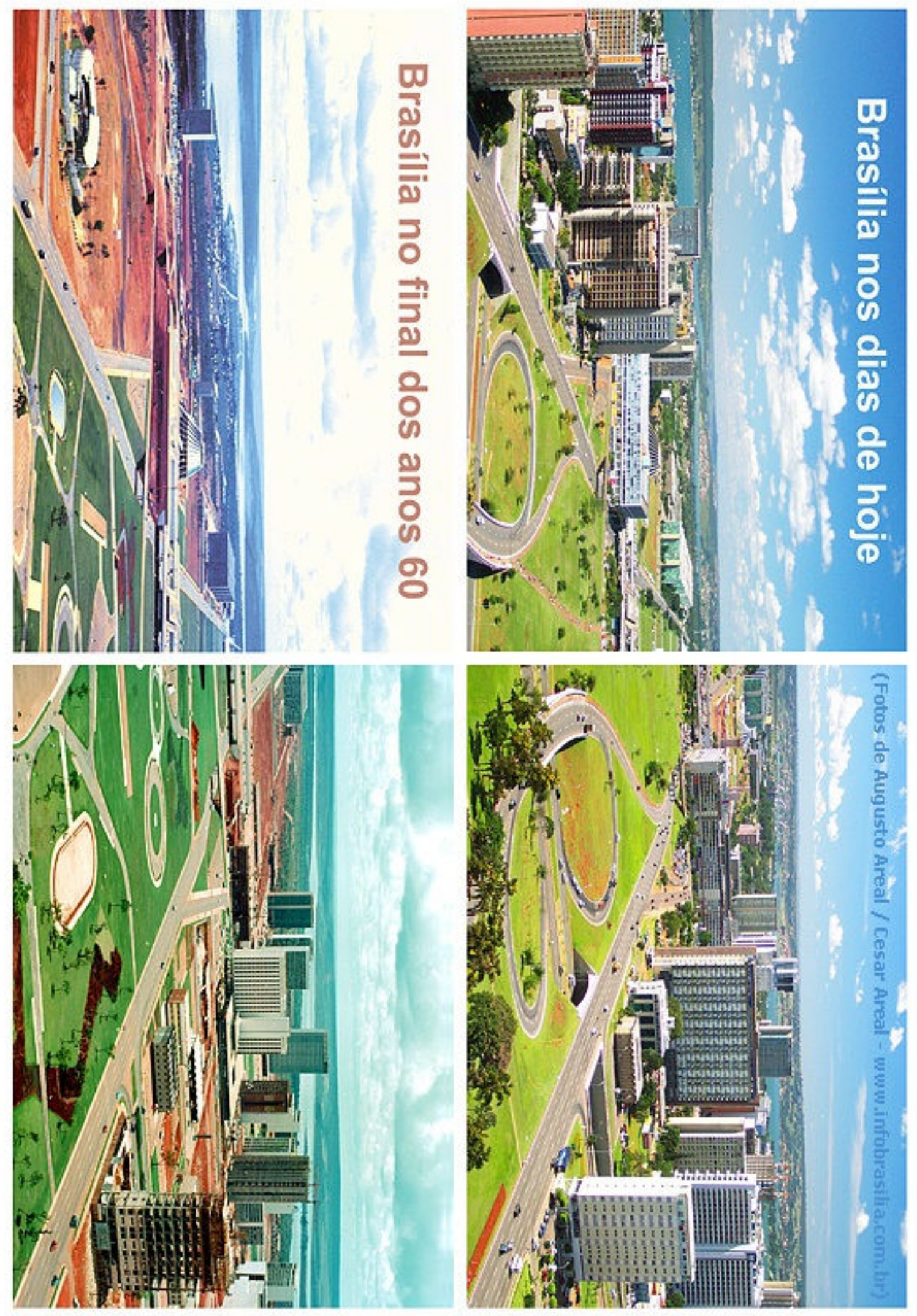


\section{ANEXO B: TERCEIRO COLOCADO NO CONCURSO PARA O PROJETO DA NOVA CAPITAL}

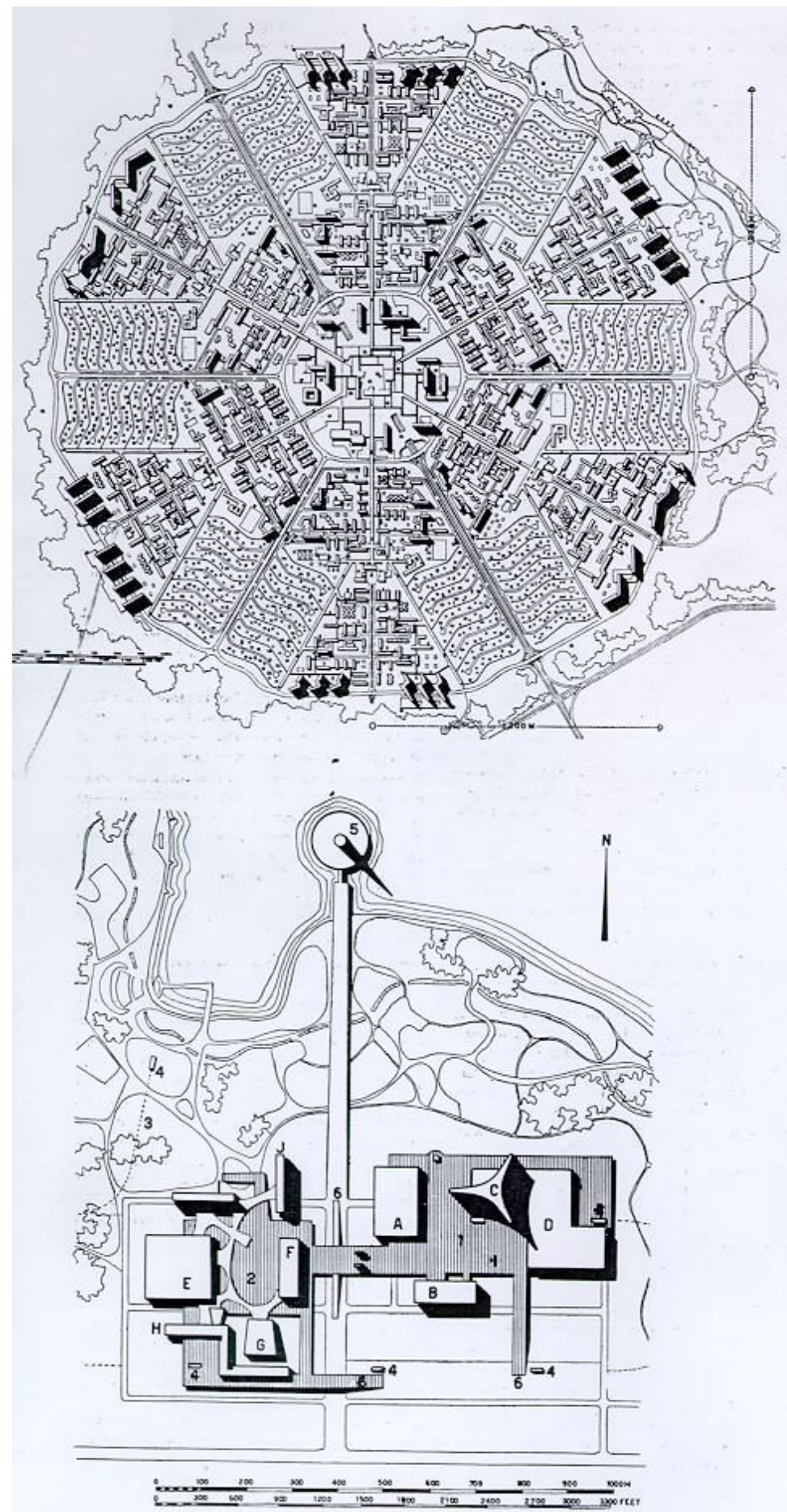

Parque Federal

1 - Edificio do Legislativo

A - Praça dos Trés Poderes

B - Edificio do Judiciário

C - Edificio do Executivo

D - Edificios da Economia, do Trabalho e Dejesa

2 - Praģa da Cullura

E - Museu e Galeria Nacional.

F - Biblioteca

G - Teatro

H - Edificio da Ciéncia

I - Secretariado

$\mathrm{J}$ - Internacional

3 - Ferrovia subterránea

1 - Estaçāo da Ferrovia

5 - Usina Elétrica

6 - Rampa.

No terreno nivelado, atrús das praças:

Acessos ao parque e aos edificios. 
ANEXO C: SAMAMBAIA COM VISTA DA ARIE JK AO FUNDO

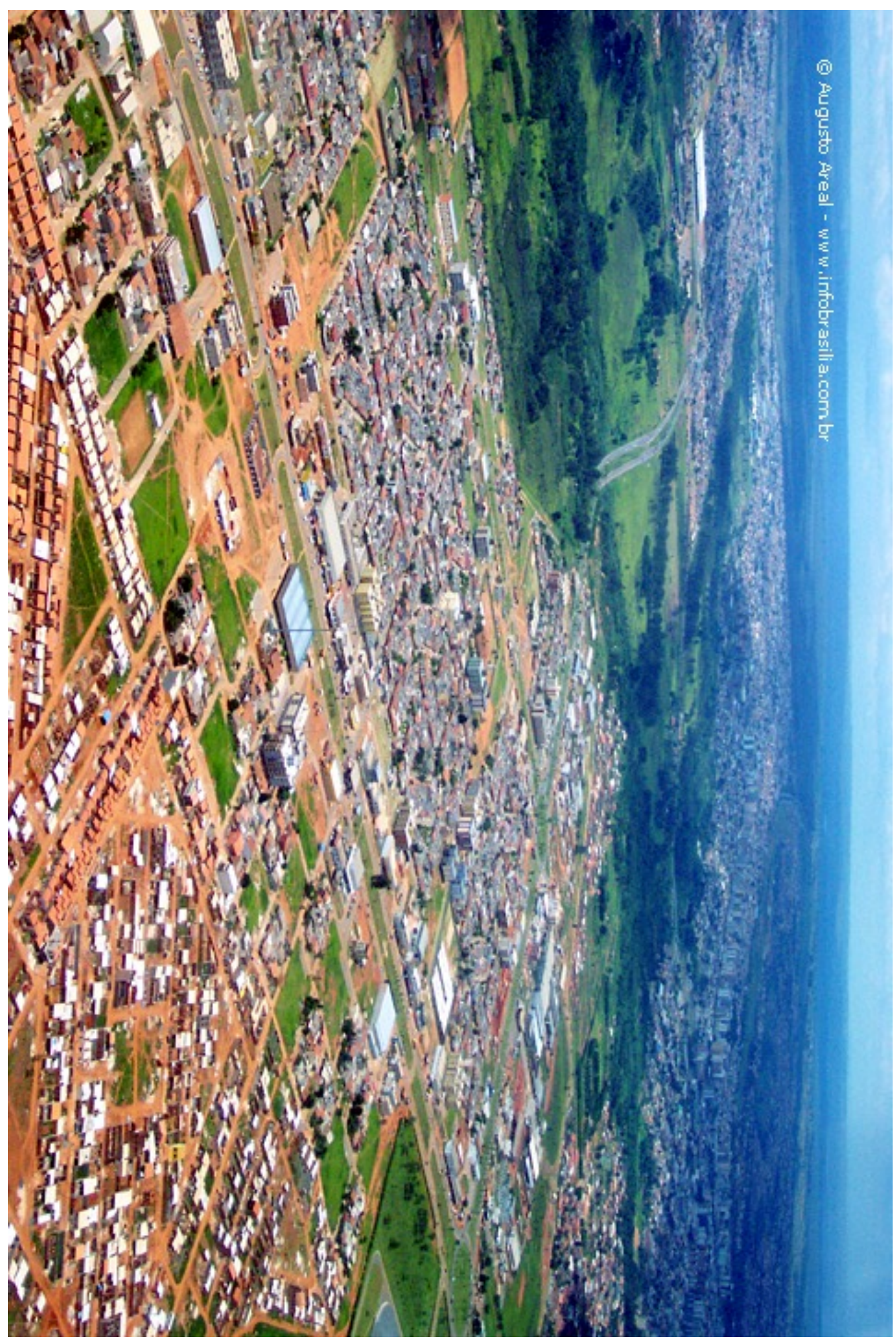


ANEXO D: TAGUATINGA COM VISTA DA ARIE JK AO FUNDO

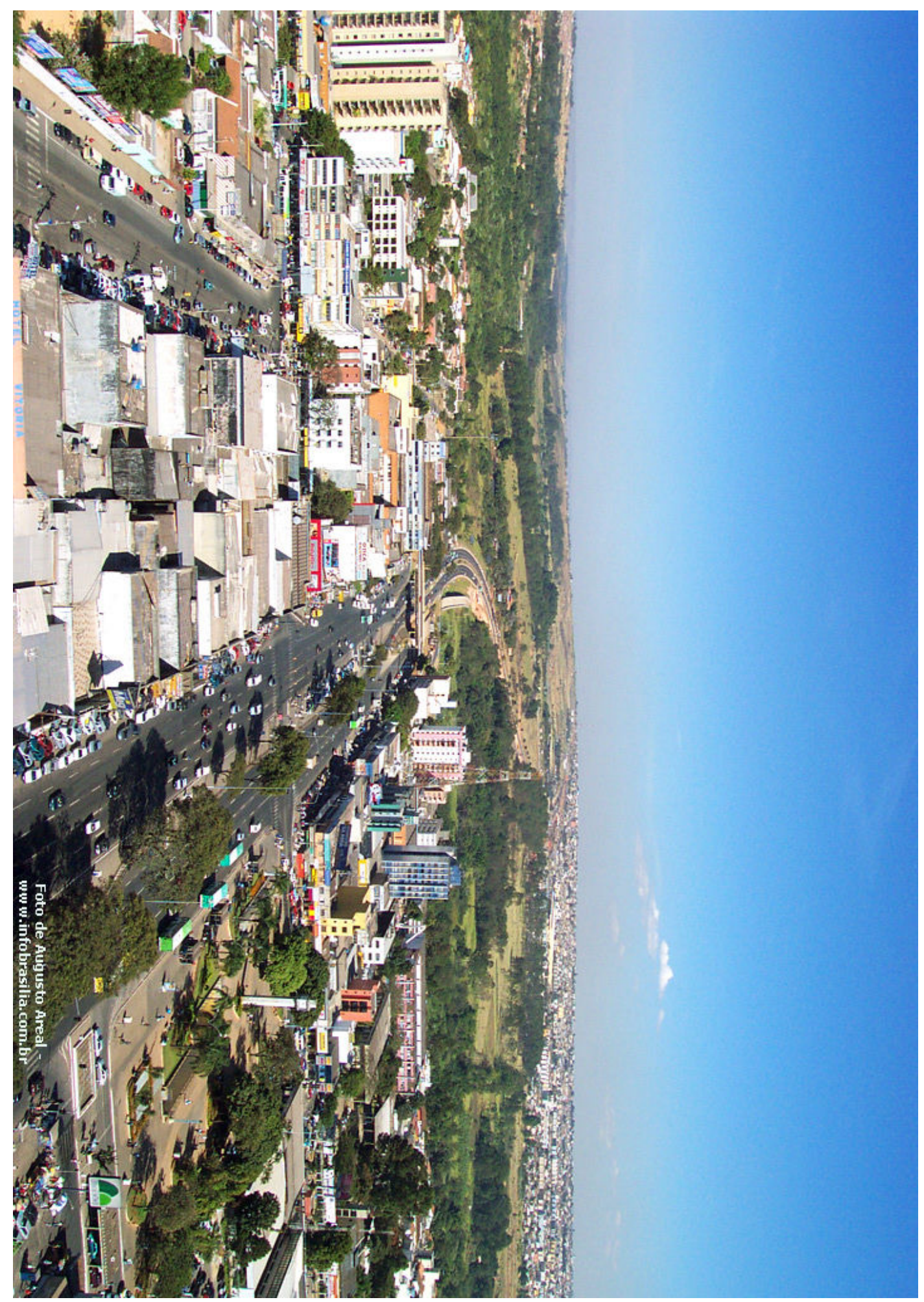


ANEXO E: IMAGEM AÉREA DE CEILÂNDIA

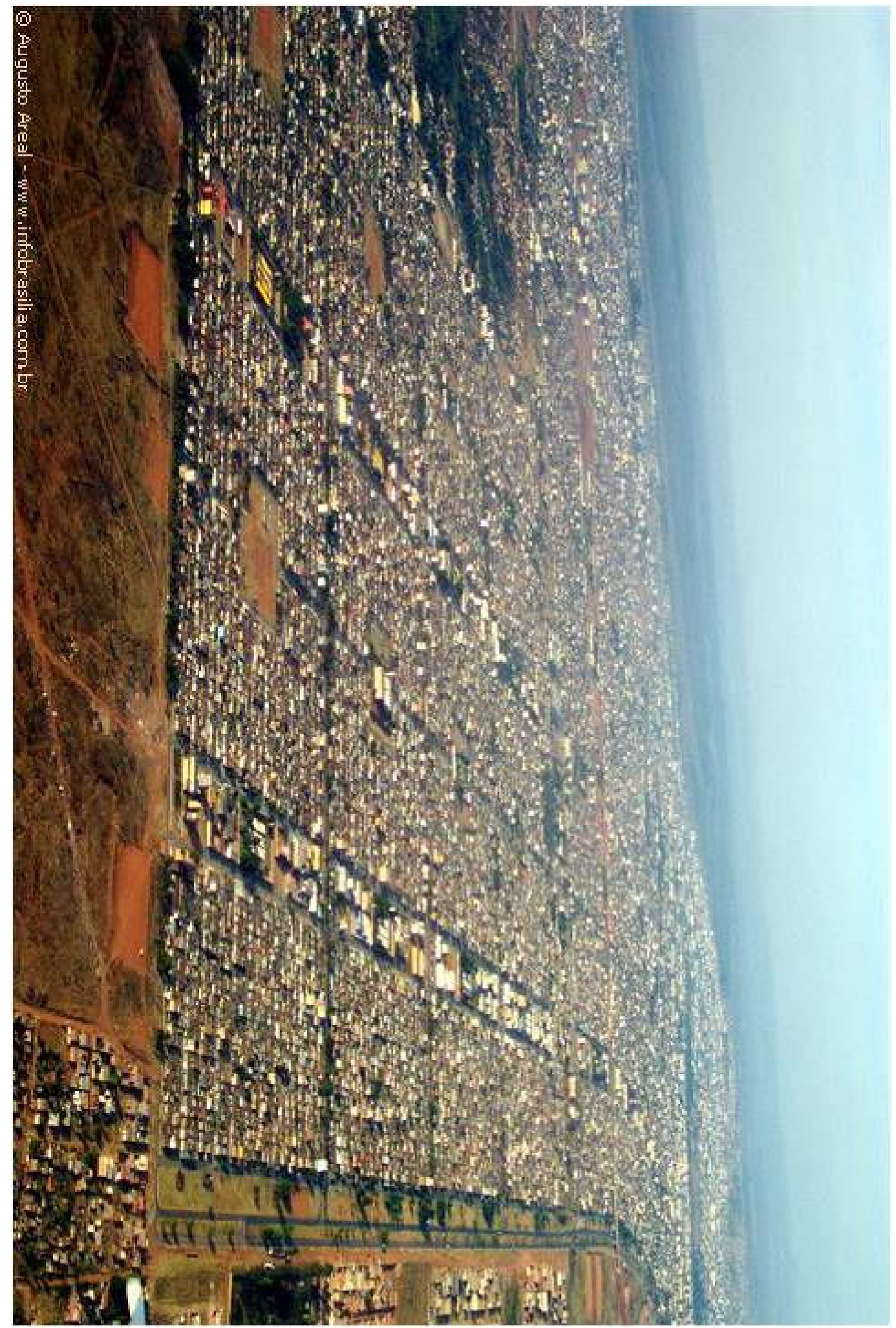


ANEXO F: IMAGENS DE SATÉLITE DA ARIE JK E SUAS ÁREAS LIMÍTROFES
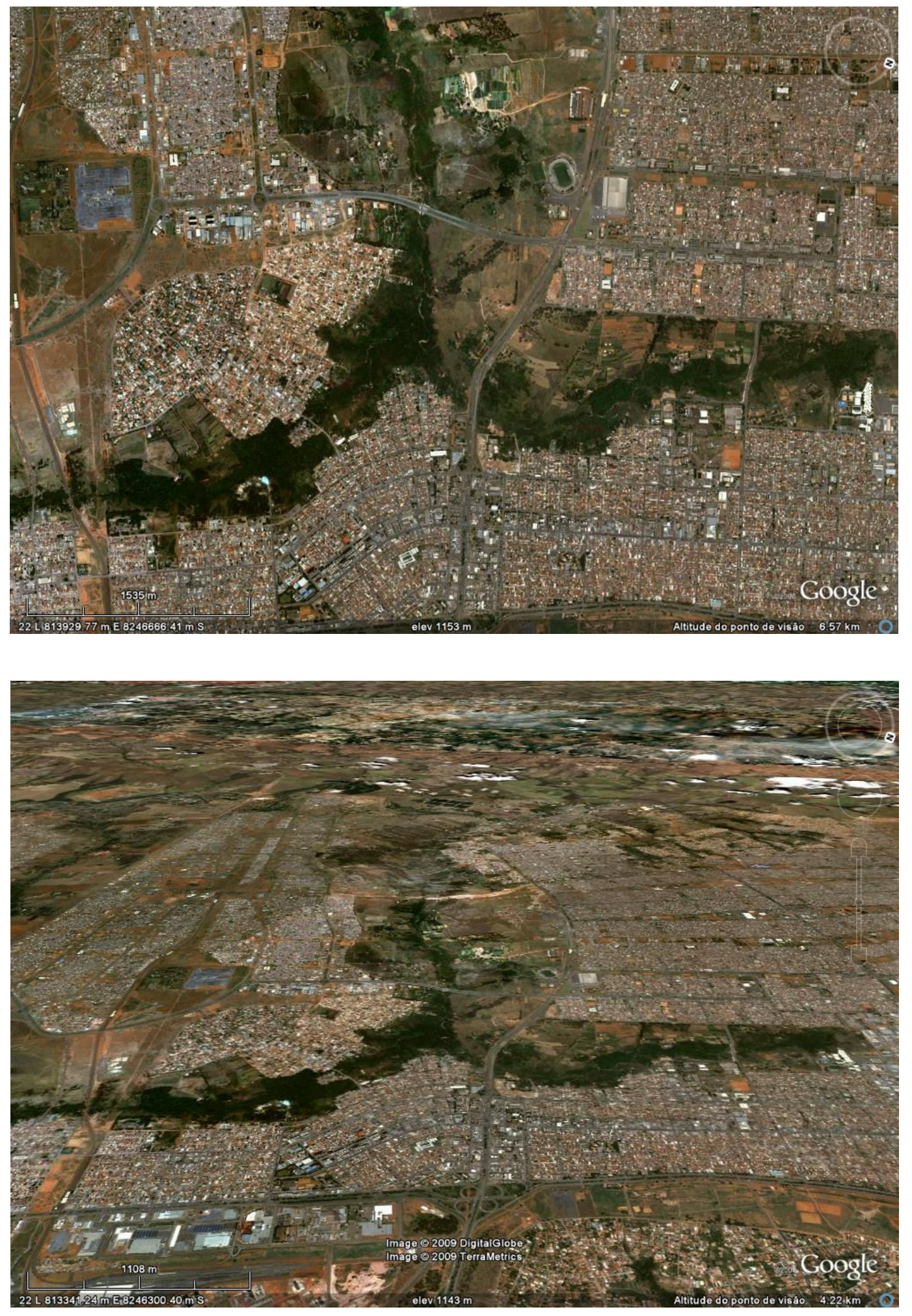
ANEXO G: IMAGENS - SAÍDAS DE CAMPO NA ÁREA DE ESTUDO
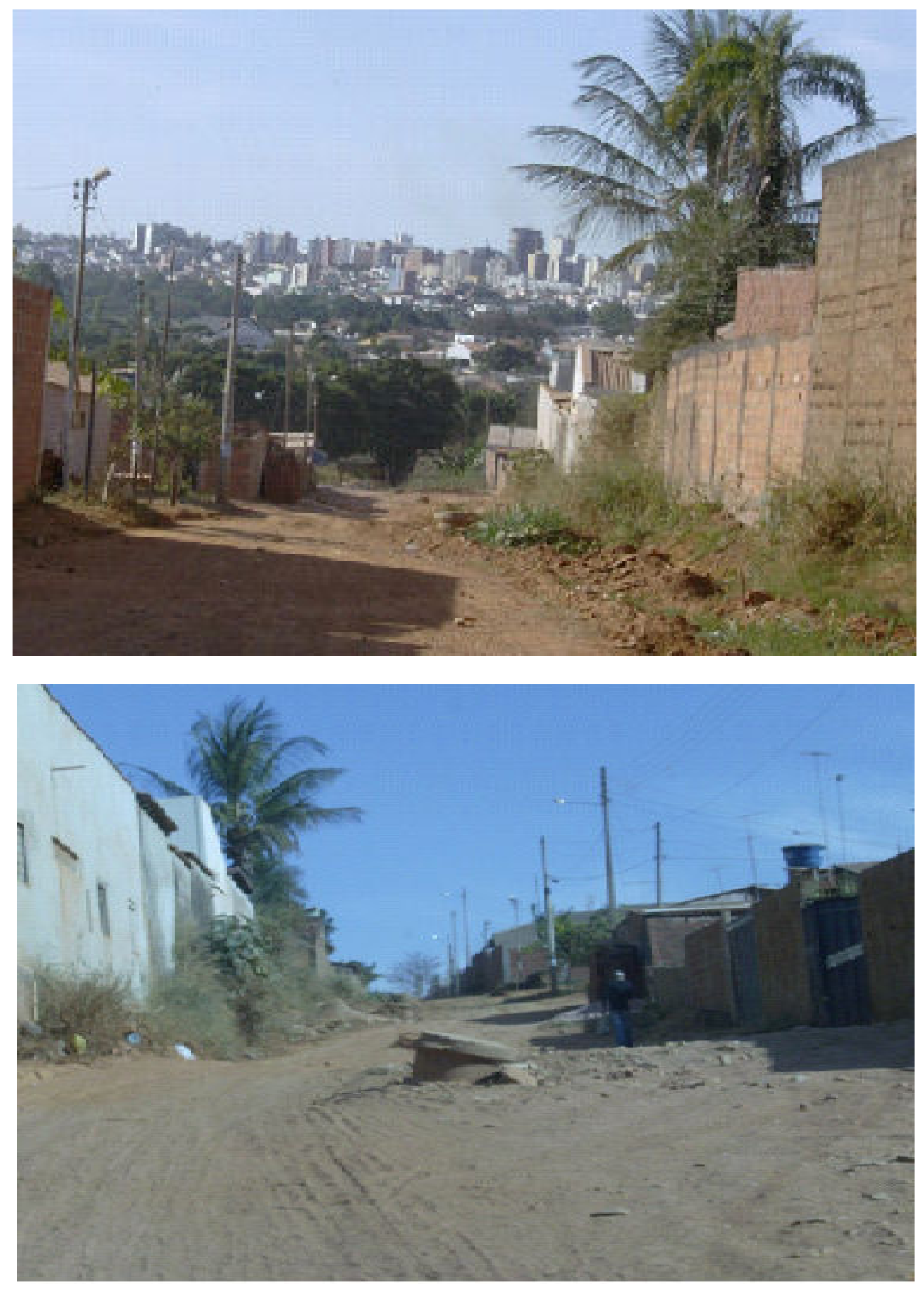